\title{
PENERAPAN PEMBELAJARAN DENGAN PENDIDIKAN MATEMATIKA REALISTIK (PMR) SECARA BERKELOMPOK UNTUK MENINGKATKAN KEMAMPUAN PEMECAHAN MASALAH MATEMATIS SISWA DI KELAS X SMA
}

Oleh:

Atik Krismiati

Guru SMA Aloysius Bandung

atik.krismiati@gmail.com

\begin{abstract}
Tujuan dari penelitian ini adalah untuk mengetahui peningkatan kemampuan pemecahan masalah matematis serta kinerja siswa. Subyek populasi dalam penelitian ini adalah siswa SMA Aloysius Bandung. Pendekatan yang digunakan dengan PMR. Instrumen yang digunakan terdiri dari: tes kemampuan pemecahan masalah dan aktivitas siswa selama pembelajaran. Secara keseluruhan siswa yang pembelajaran pemecahan masalah dengan metode PMR lebih baik dalam meningkatkan kemampuan pemecahan masalah, yaitu terlihat dengan adanya peningkatan dari siklus I ke siklus II. Kesulitan siswa terutama pada permasalahan dengan aspek argumentasi dan keakuratan. Selain itu kelebihan dari metode ini siswa lebih terlihat menyukai yaitu terlihat dengan antusiasnya mengerjakan tugas-tugas dari guru serta memberi alasan secara geometri, kreativitas, dan generalisasi yang sebagian besar perwujudannya dilakukan oleh siswa sendiri. Berdasarkan respon dan hasil akhir LKS menunjukkan aktivitas, dan kinerja yang lebih meningkatkan untuk setiap siklusnya
\end{abstract}

Kata Kunci : Pendidikan Matematika Realistik, Pemecahan Masalah Matematis

The purpose of this study is to determine the increase in mathematical problem-solving skills as the well as student performance. The population subjects in this study are the high school students Aloysius Bandung. The approach applied is PMR . The used instruments consisted of : problem solving ability testing and students activities during the learning process. Overall, the students who are applying PMR method is better, which is seen from the increasing cycle I to cycle II. The primary students difficulties are on problems with aspects of argumentation and accuracy. However the advantages of this method the students look more enthusiastic in doing the tasks given are by the teachers, and they are also able to give geometrical and creative reasons. Which most of its manifestations are generally made by the students themselves. Based on the response and the final results of the students worksheets, they show the improvise activities performance in every cycle.

Key words : realistic mathematics education, mathematical problem solving 


\section{Pendahuluan}

\section{A. Latar Belakang}

Salah satu masalah dalam pembelajaran matematika di SMA kelas X adalah rendahnya kemampuan siswa dalam memecahkan masalah (soal cerita), khususnya soal non rutin atau terbuka (open ended). Hasil diskusi dengan salah satu seorang guru matematika SMA Aloysius mengidentifikasi beberapa kelemahan siswa, antara lain: memahami kalimat-kalimat dalam soal, tidak dapat membedakan informasi yang diketahui dan permintaan soal, tidak lancar menggunakan pengetahuan yang diketahui, mengubah kalimat cerita menjadi kalimat matematika, menggunakan cara-cara yang berbeda-beda dalam merencanakan penyelesaian suatu masalah. Apabila dipersempit kelemahan itu terutama pada kemampuan siswa dalam memahami masalah dan merencanakan suatu penyelesaiannya.

Dengan mengurai beberapa kemungkinan penyebab kelemahan siswa tersebut antara lain: (1) Pola pembelajaran selama ini masih dengan tahapan memberikan informasi tentang materi-materi, memberikan contoh-contoh dan berikutnya latihan, tetapi jarang soal cerita. Hal ini karena anggapan bahwa soal cerita pasti akan sulit untuk dipahami siswa, sehingga tidak menjadi prioritas untuk diajarkan. (2) Dalam penyelesaian suatu masalah kurang diajarkan strategi-strategi penyelesaian yang bervariasi, serta tidak memberikan kesempatan siswa menunjukkan idea tau representasinya sendiri.

Memperhatikan akar masalah itu, maka perlu dipikirkan cara mengatasinya. Apalagi pemecahan masalah matematis menjadi fokus utama dalam pembelajaran matematika, sehingga siswa harus difasilitasi dalam pembelajarannya agar kemampuan tersebut menjadi lebih baik. Hal ini dikuatkan oleh The National Council of Teachers of Mathematics (NCTM) (dalam Schoenfeld, 1992: 3) bahwa tujuan utama pembelajaran matematika adalah pemecahan masalah. NCTM (2000) juga menegaskan bahwa pemecahan masalah bukan hanya sekedar tujuan dari belajar matematika, tetapi juga merupakan alat utama untuk melakukannya. tujuan pembelajaran matematika yang salah satunya menitik beratkan mengembangkan kemampuan pemecahan masalah. Pendekatan untuk peningkatan mutu siswa di sekolah, peneliti lebih menekankan pada proses pembelajarannya, karena proses tersebut merupakan tugas dan tanggung jawab professional guru sehari-hari. Bila mengacu pada identifikasi penyebab kelemahan tersebut, maka dalam mendorong siswa untuk memahami masalah, meningkatkan kemampuan pemecahan masalah siswa dalam menyelesaikan soal secara aktif dan menemukan sendri penyelesainnya. Selain itu mendorong pembelajaran yang berpusat pada siswa dan guru sebagai fasilitator.

Bila meninjau cara pembelajaran yang diharapkan itu, maka salah satu pendekatan pembelajaran yang memiliki sifat dan karakter tersebut adalah pembelajaran yang sesuai dengan dunia nyata atau sering disebut dengan Pendidikan Matematika 
Realistik (PMR). Dalam Pendidikan Matematika Realistik (PMR) masalah-masalah yang bersifat kontekstual atau realistik dijadikan sebagai titik awal dalam pembelajaran, yang kemudian dimanfaatkan oleh siswa dalam melakukan proses matematisasi dan pengembangan model matematika. Melalui masalah yang bersifat kontekstual tersebut, siswa dilatih untuk dapat memecahkan masalah dengan caranya sendiri sekaligus berlatih memahami cara yang digunakan siswa lain. Pada prinsip ini siswa diberikan kesempatan untuk menunjukkan kemampuannya dalam memecahkan masalah matematis. Dengan demikian PMR memungkinkan digunakan untuk meningkatkan kemampuan pemecahan masalah matematis siswa.

\section{B. Rumusan Masalah}

Rumusan masalah dalam penelitian ini adalah apakah penerapan pembelajaran dengan Metode Pendidikan Matematika Realistik secara berkelompok akan meningkatkan kemampuan pemecahan masalah matematis siswa kelas X SMA Aloysius Bandung?

\section{Tujuan Penelitian}

Tujuan umum penelitian tindakan ini adalah :

1. Meningkatkan kemampuan pemecahan masalah matematis siswa kelas X SMA Aloysius Bandung.

2. Menerapkan pembelajaran dengan Pendidikan Matematik Realistik di kelas X SMA Aloysius Bandung.

3. Meningkatkan Pemahaman Konsep (Conceptual understanding), Proses dan strategi (Processes and Strategies), Komunikasi dan Koneksi (Communication and Connecting Path), Argumentasi (Verification), Keakuratan (Accuracy) dalam menyelesaikan menyelesaikan masalah matematis.

\section{Manfaat Penelitian}

Hasil pelaksanaan Penelitian Tindakan Kelas yang merupakan "self-reflective teaching" ini akan memberikan kontribusi yang berarti bagi perorangan atau instansi dibawah ini :

1. Bagi Guru : Guru dapat mengetahui strategi atau pendekatan pembelajaran yang bervariasi untuk memperbaiki dan meningkatkan sistem pembelajaran di kelas. Dengan contoh penelitian tindakan ini, guru akan terbiasa melakukan penelitian kecil yang bermanfaat bagi perbaikan pembelajaran dan karir guru.

2. Bagi Siswa : Hasil penelitian ini akan sangat bermanfaat bagi siswa untuk meningkatkan kemampuan pemecahan masalah matematika yang berguna untuk materi selanjutnya ataupun ketika di luar sekolah.

3. Bagi SMA : Hasil penelitian ini akan memberikan sumbangan berupa prototype/ media pembelajaran yang dapat dimanfaatkan guru-guru bidang studi matematika atau non matematika serta dapat memperbaiki pembelajaran guru di sekolah. 


\section{E. Definisi Operasional}

Kemampuan pemecahan masalah geometri adalah kemampuan menyelesaikan masalah menurut Oregon yang meliputi empat kemampuan sebagai berikut :
a. Pemahamaan Konsep
b. Proses dan Strategi
c. Komunikasi dan Koneksi
d. Argumentasi
e. Keakuratan

\section{F. Hipotesis}

Hipotesis dalam penelitian ini adalah Kemampuan pemecahan masalah matematis siswa (Pemahaman Konsep, Proses dan strategi, Komunikasi dan koneksi, Argumentasi, Keakuratan) dapat meningkat dengan menggunakan metode PMR secara berkelompok.

\section{Hasil Penelitian dan Pembahasan}

\section{A. Hasil Penelitian Siklus I}

Dalam penelitian ini secara keseluruhan dilaksanakan 2 siklus dan terdiri 4 pertemuan, sehingga masing-masing siklus terdiri dari 2 pertemuan.

\section{Perencanaan}

Kegiatan yang dilakukan dalam tahap ini adalah :

1. Menyusun Rencana Pembelajaran dan Lembar Kerja Siswa, termasuk memvalidasinya. Rencana Pembelajaran yang dibuat terdiri dari 4 RPP. RPP 1 : Trigonometri, intinya merupakan pemberian materi tentang menemukan sifatsifat sudut-sudut istimewa. Model pembelajaran yang digunakan adalah model pembelajaran pemecahan masalah dengan pendekatan PMR. Pada awalnya siswa diarahkan menemukan sifat-sifat sendiri, kemudian guru memberikan penjelasan klarifikasi dan penegasan tentang materi yang yang dibahas. Selanjutnya pembelajaran pemecahan masalah dengan pendekatan PMR, siswa dilatih untuk memecahkan masalah dengan menemukan beberapa cara penyelesaian maupun jawaban. Guru meminta siswa mengajukan masalah sendiri untuk berikutnya dalam LKS 1 dan membahasnya secara klasikal tanpa meminta siswa untuk mengumpulkan hasil tugas pengajuan masalah itu dan kemudian diberikan tes formatif. RPP 2: Trigonometri, intinya memuat langkah-langkah pembelajaran bagaimana menerapkan sifat-sifat sudut istimewa untuk menyelesaikan masalah. Dalam prosesnya setelah siswa menyelesaikan masalah, mereka diminta untuk membuat soal sendiri yang berbeda dari sebelumnya. Soal hasil tugas itu saling ditukarkan pada kelompok lain untuk dikerjakan dan hasilnya untuk beberapa kelompok dibahas bersama di depan kelas. 
Tujuan proses ini agar siswa berlatih memahami informasi soal, dan menyelesaikan soal dengan jawaban maupun cara yang berbeda, sehingga kemampuan pemecahan masalah siswa meningkat. Tugas-tugas itu tertuang dalam LKS 2, RPP 3 dan RPP 4: Penerapan Trigonometri, inti materinya sama dengan RPP 2 dan merupakan kelanjutan siklus penelitian.

Lembar kerja siswa terdiri dari 4 LKS yang isinya memuat materi yang digunakan dalam pembelajaran. Setiap LKS memuat tugas-tugas pemecahan masalah. Validasi meliputi kesesuaian rancangan pembelajaran dengan kompetensi dalam kurikulum, keterbacaan LKS maupun RPP yang digunakan. Hasilnya RPP dan LKS sesuai dengan kompetensi yang terdapat dalam kurikulum, waktu 2 x 40' untuk satu RPP tidak cukup sehingga terdapat materi soal yang tidak dibahas hanya sebagai tugas rumah, keterbatasan isi LKS cukup dipahami siswa.

2. Membuat lembar pengamatan, dan foto-foto selama pembelajaran untuk mengetahui bagaimana aktivitas siswa selama pembelajaran, aktivitas guru dan kesesuaiannya dengan RPP yang dirancang.

3. Membuat lembar tes diagnostik yang berfungsi sebagai alat evaluasi pemecahan masalah yaitu memuat langkah-langkah dalam memecahkan masalah, yang disarankan Oregon dalam Mathematics Problem Solving Scoring Guide dengan rincian sebagai berikut:
a. Pemahaman Konsep (Conceptual understanding)
b. Proses dan strategi (Processes and Strategies)
c. Komunikasi dan Koneksi (Communication and Connecting Path)
d. Argumentasi (Verification)
e. Keakuratan (Accuracy)

4. Membuat lembar penilaian termasuk rubriknya yang sesuai dengan kompetensi atau tujuan pembelajaran. Materi isi penilaian disesuaikan dengan tujuan penelitian untuk meningkatkan kemampuan pemecahan masalah siswa dalam belajar materi trigonometri. Penilaian didasarkan pada kebenaran siswa menyelesaikan atau menjawab soal yang disesuaikan dengan kunci lembar penilaian. Penilaian ini menekankan pada produk, sedangkan penilaian proses menggunakan penilaian kinerja siswa ketika memecahkan masalah yang terdapat dalam LKS. Penilaian didasarkan pada rubrik penilaian yang terdiri dari 5 tingkatan, yaitu Sangat Baik (4), Baik (3), Cukup (2), Kurang (1), dan Sangat Kurang (0). Kriterianya meliputi pemahaman terhadap masalah, perencanaan (memilih dan menggunakann strategi), pelaksanaan rencana dan pemeriksaan terhadap kesimpulan.

5. Menyusun strategi pengamatan dan pelaksanaan penelitian. Menetapkan kelas $\mathrm{XC}$ sebagai kelas penelitian yang terdiri 37 siswa. 


\section{Pelaksanaan}

Pelaksanaan penelitian dimulai :

1. Tes Diagonostik dilaksanakan 14 Maret 2013 selama 40 menit diikuti 37 siswa

2. Pertemuan pertama dilaksanakan 19 Maret 2013 Selama (4x 40 ') berpanduan RPP 1 dan LKS 1. Dalam pertemuan tersebut dikumpulkan data berupa kemampuan siswa dalam pemecahan masalah melalui LKS 1 dan penilaian tertulis pertama melalui lembar penilaian 1. Selain itu diadakan pengamatan aktivitas siswa, serta penilaian kinerja yang dilakukan siswa.

3. Pertemuan kedua dilaksanakan 20 Maret 2013 selama 2 jam $(2 \times 40$ ') berpanduan RPP 2 dan LKS 2. Dalam pertemuan tersebut dikumpulkan data berupa kemampuan pemecahan masalah siswa melalui LKS 2. Selain itu diadakan pengamatan aktivitas siswa, serta penilaian kinerja yang dilakukan siswa.

\section{Pengamatan}

Pada tahap ini dilaksanakan proses observasi terhadap pelaksanaan tindakan dengan menggunakan lembar observasi yang telah dibuat dan mengadakan penilaian untuk mengetahui kemampuan pemecahan masalah siswa.

1. Hasil tes diagnostic (awal) menunjukkan kemampuan pemecahan masalah siswa, seperti pada tabel 4.1 berikut :

Tabel 4.1

Persentase Kemampuan Pemecahan Masalah Matematis tiap indicator

\begin{tabular}{|c|c|c|c|c|c|}
\hline $\begin{array}{c}\text { Kemampuan } \\
\text { Pemecahan } \\
\text { Masalah }\end{array}$ & $\begin{array}{c}\text { Pemahaman } \\
\text { Konsep }\end{array}$ & $\begin{array}{c}\text { Proses } \\
\text { dan } \\
\text { Strategi }\end{array}$ & $\begin{array}{c}\text { Komunikasi } \\
\text { dan Koneksi }\end{array}$ & Argumentasi & Keakuratan \\
\hline $\begin{array}{c}\text { Banyak } \\
\text { Siswa dari 37 }\end{array}$ & $45,5 \%$ & $1,25 \%$ & $1 \%$ & $5 \%$ & $3,5 \%$ \\
\hline
\end{tabular}

Skor rata-rata siswa adalah 16,42 dengan skor maksimal 120. Jadi kemampuan pemecahan masalah siswa masih rendah dan belum memenuhi ketuntasan yang batasnya harus melebihi skor 60 dari skor maksimum 120.

2. Pada pertemuan pertama didapatkan data skor siswa dalam menyelesaikan soal dan pemecahan masalah yang terdapat dalam LKS 1 . Hasilnya seperti dalam tabel 4.2 berikut : 
Tabel 4.2 Persentase Kemampuan Pemecahan Masalah LKS 1

\begin{tabular}{|c|c|c|c|c|c|}
\hline $\begin{array}{c}\text { Kemampuan } \\
\text { Pemecahan } \\
\text { Masalah }\end{array}$ & $\begin{array}{c}\text { Pemahaman } \\
\text { Konsep }\end{array}$ & $\begin{array}{c}\text { Proses } \\
\text { dan } \\
\text { Strategi }\end{array}$ & $\begin{array}{c}\text { Komunikasi } \\
\text { dan Koneksi }\end{array}$ & Argumentasi & Keakuratan \\
\hline $\begin{array}{c}\text { Banyak } \\
\text { Siswa dari } 37\end{array}$ & $14,1 \%$ & $19,5 \%$ & $8,1 \%$ & $41,7 \%$ & $20,9 \%$ \\
\hline
\end{tabular}

Skor rata-rata siswa dengan skor maksimal 120 Bila batas ketuntasan siswa sebesar $65 \%$ dari skor maksimal, maka terdapat 7 siswa atau hanya $22.34 \%$ yang mencapai ketuntasan dengan skor lebih dari atau sama dengan kemampuan pemecahan masalah siswa masih rendah, sehingga masih perlu ditingkatkan untuk pertemuan berikutnya. Berikut adalah contoh soal yang benar dibuat salah satu kelompok siswa yang mengadakan pengukuran di dalam

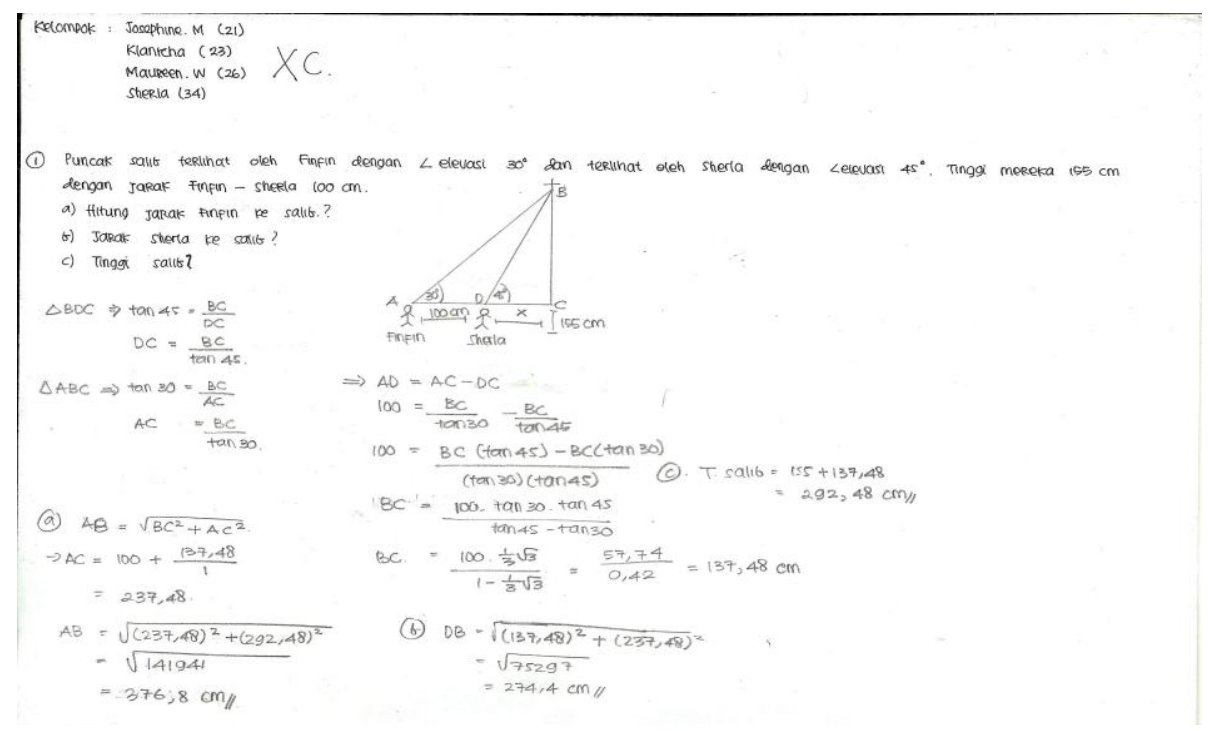

Setelah melakukan pengukuran beberapa kelompok siswa mempresentasikan hasil pekerjaannya didepan kelas, seperti terlihat dalam gambar di bawah ini 


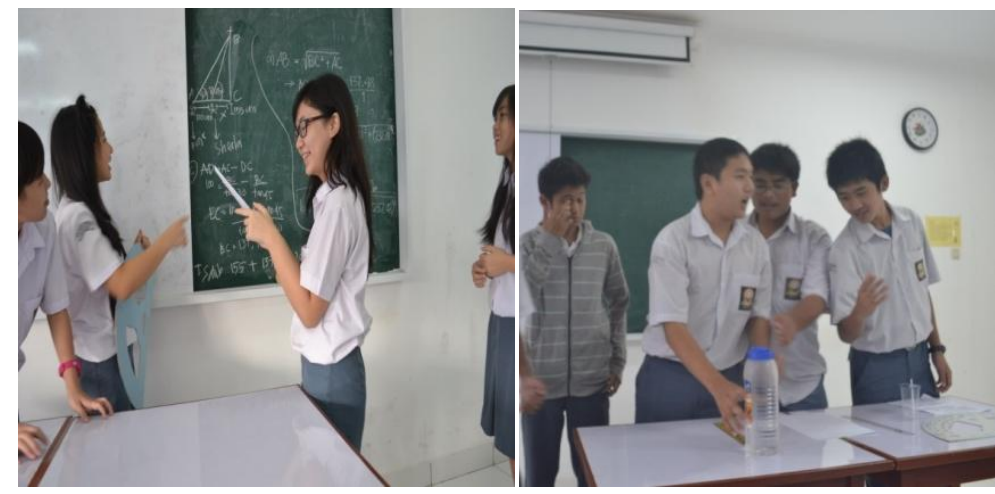

Gambar 4. 1 Persentasi siswa

3. Pada pertemuan kedua tanggal 26 Maret 2013 didapatkan data skor siswa dalam mengajukan soal yang terdapat pada LKS 1. Dalam LKS 1 terdapat beberapa kesalahan yang mengalami kelemahan dalam aspek pemecahan masalah.

Kesalahan siswa dalam mengajukan masalah adalah:

a. Tidak menyebutkan pertanyaan soal

b. Soal benar tetapi penyelesaian salah

c. Tidak diketahui gambar atau kurang informasi

Untuk salah satu contoh pekerjaan siswa yang benar pada Lembar kerja siswa 1 (LKS 1) yang terlihat pada gambar 4.2 dan untuk nomor-nomor yang lain bisa dilihat pada lampiran

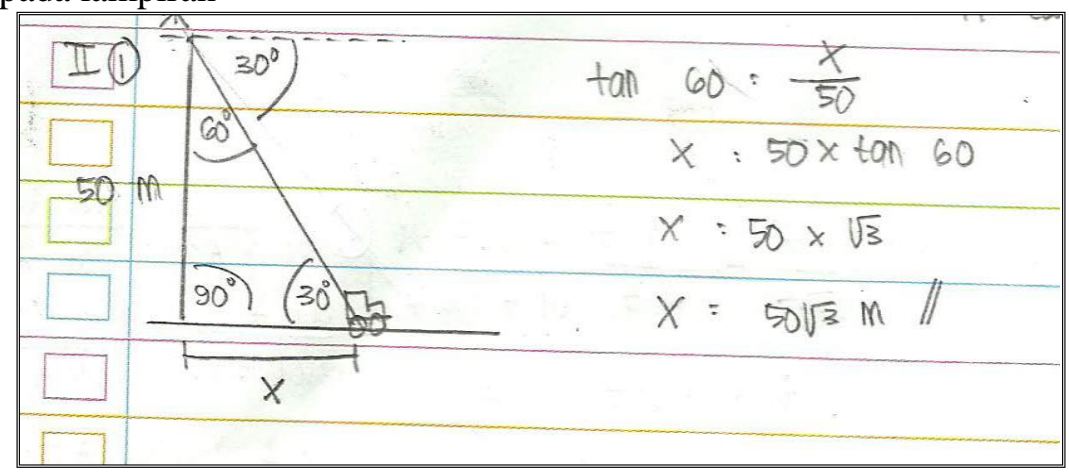

Gambar 4.2 Pekerjaan siswa LKS 1

Hasil kemampuan pemecahan masalah siswa pada aspek pemahaman konsep mengalami peningkatan yang terjadi pada LKS 1, untuk persentase setiap aspeknya terlihat pada grafik 4.1 


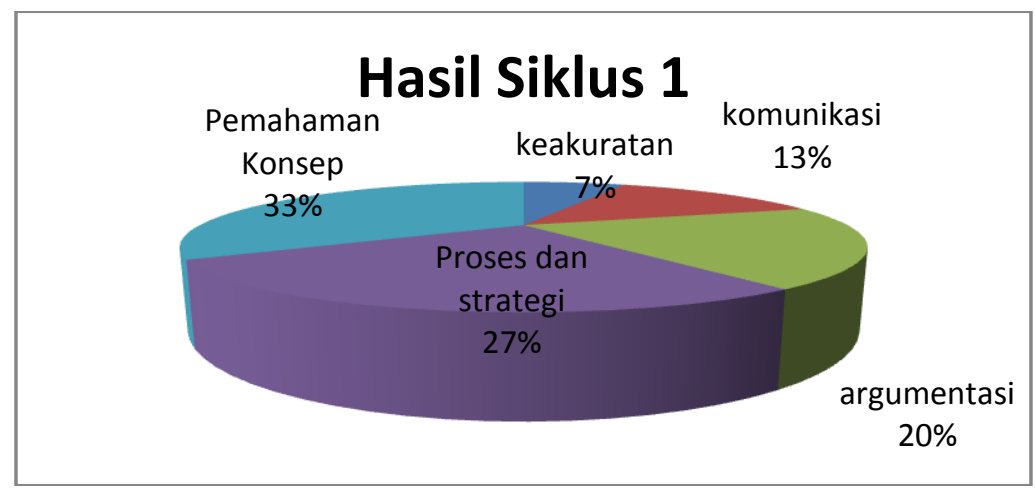

Grafik 4.1 Persentase kemampuan pemecahan masalah

Skor rata-rata dari skor maksimal 120, terdapat 7 siswa yang mencapai ketuntasan pada siklus I. Hasil ini meskipun kecil menunjukkan kenaikan skor dari proses pada belajar siswa Kemampuan siswa dalam mengajukan soal sudah meningkat daripada tes diagnostik sebelumnya. Kesalahan siswa dalam pemecahan masalah siswa adalah:

a. Kurang informasi

b. Hasil penilaian kinerja pada dua pertemuan menunjukan perkembangan

Berdasarkan tabel kinerja siswa dalam memecahkan masalah mengalami kemajuan atau peningkatan. Rubrik atau kategori penilaian dapat dilihat pada lampiran. Hasil pengamatan aktivitas siswa selama 2 pertemuan terlihat menyenangkan, terlihat dari beberapa foto-foto siswa ketika pembelajaran berlangsung. hasil pengamatan aktivitas siswa ketika pembelajaran tiap pertemuan. Hasil pengamatan menunjukan pada dua pertemuan terjadi dari kurang aktif menjadi aktif. Hal ini kemungkinan karena pembelajaran berkelompok ini menuntuk setiap siswa untuk aktif terlibat dan sifat materi pada dua pertemuan itu berbeda. Pertemuan pertama siswa di tuntut lebih aktif karena isi materi menemukan penerapan trigonometri dengan menyelesaikan soal cerita (pemecahan masalah) dan pertemuan kedua siswa dituntut untuk lebih berani mempresentasikan dan mengemukakan ide-ide yang dimiliki oleh setiap kelompok.

\section{Refleksi}

Berdasarkan hasil analisis dari pengamatan pada siklus pertama penelitian di dapatkan hasil pemecahan masalah siswa masih rendah meskipun bila di bandingkan dari tes diagnostik, dan pertemuan pertama mengalami kemajuan walaupun hanya beberapa aspek.dari pemecahan masalah. Selain itu ketuntasan belajar siswa pada tes penilaian pertemuan ketika akhir pembelajaran, maka hal ini perlu di perbaiki pada siklus berikutnya. 


\section{B. Hasil Penelitian Siklus II}

\section{Perencanaan}

Sesuai hasil refleksi maka di lakukan perubahan-perubahan sebagai berikut.

1. Pada pertemuan ketiga rancangan pada RPP 3 siswa diminta untuk mengadakan pengukuran di lingkungan sekolah. Untuk kemudian siswa diberikan tugas yang selanjutnya dijadikan pekerjaan rumah untuk di bahas pada pertemuan selanjutnya. Guru tetap menilai kinerja maupun formatif siswa. Seorang siswa tetap di minta mengerjakan dan membahas di depan kelas sekaligus tugas pengajuan soal dan guru memberi penjelasan terhadap soal yang sebaiknya bagaimana seperti RPP 2. Sebagai nilai formatif siswa di ambil dari hasil tes siswa mengerjakan soal LKS 2. Untuk beberapa contoh gambar kegiatan siswa diluar kelas terlihat dibawah ini.
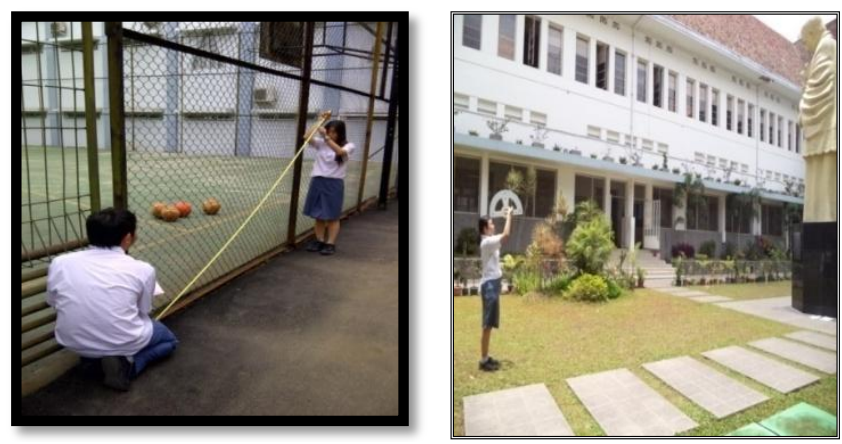

2. Pada pertemuan ke empat tetap mengunakan rancangan pada RPP 4 seperti rancangan awal. Nilai formatif didasarkan pada soal yang di pilih dari soal-soal yang di buat siswa dan menurut guru dapat di kerjakan oleh semua siswa dan memenuhi kebenaran soal, dalam hal ini di pilih soal yang dia buat oleh salah satu siswa.

\section{Pelaksanaan}

Pelaksanaan pada pertemuan ketiga dan keempat sesuai dengan rencana. Guru dan pengamatan menilai kinerja siswa dan penganmatan mengamati guru dalam melaksanakan pembelajaran. Hanya pada pertemuan keempat, pengamatan tidak melakukan pengamatan tertulis terhadap aktivitas siswa dan guru maupun pengelolaan pembelajaran seperti sebelumnya. Selain itu mereka tidak menilai kinerja siswa. Hal tersebut karena anggapan aktivitas siswa, guru maupun pelaksanaan dan pengelolaan pembelajaran telah sesuai dengan yang di rancang sebelumnya, sehingga data tertulis tentang hal itu tidak di ketahui. Hanya guru yang mengamati kinerja siswa secara tertulis.

\section{Pembahasan}

Hasil penilaian kinerja pada siklus II menunjukkan perkembangan sebagai berikut : 
Tabel 4.4 Hasil Penilaian Kinerja Siswa pada siklus I dan II

\begin{tabular}{|c|c|c|}
\hline Pertemuan & I & II \\
\hline \multicolumn{3}{|c|}{ Rata-rata Nilai } \\
\hline Deskripsi & 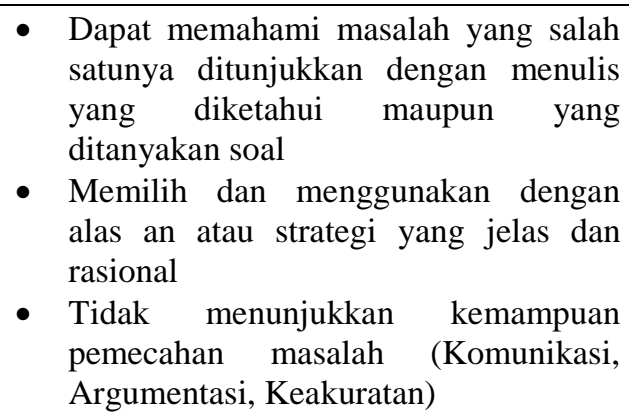 & $\begin{array}{l}\text { - } \begin{array}{l}\text { Dapat melakukan } \\
\text { perhitungan atau membuat } \\
\text { model/gambar dengan tepat }\end{array} \\
\text { - Dapat memahami masalah } \\
\text { yaitu dengan menuliskan } \\
\text { yang diketahui } \\
\text { Kurang menunjukkan } \\
\text { pemecahan masalah yang } \\
\text { maksimal pada aspek } \\
\text { argumentasi dan keakuratan }\end{array}$ \\
\hline
\end{tabular}

Berdasarkan tabel dikerja siswa memecahkan masalah mengalami kemajuan atau peningkatan. Rubrik atau kategori penilaian dapat dilampiran. Perubahan kemampuan pemecahan masalah pada siklus II ini lebih mengalami peningkatan dari pada siklus I, ini bisa terlihat pada perubahan kemampuan pemecahan masalah tiap siklus dapat di lihat pada grafik 4.2 berikut.

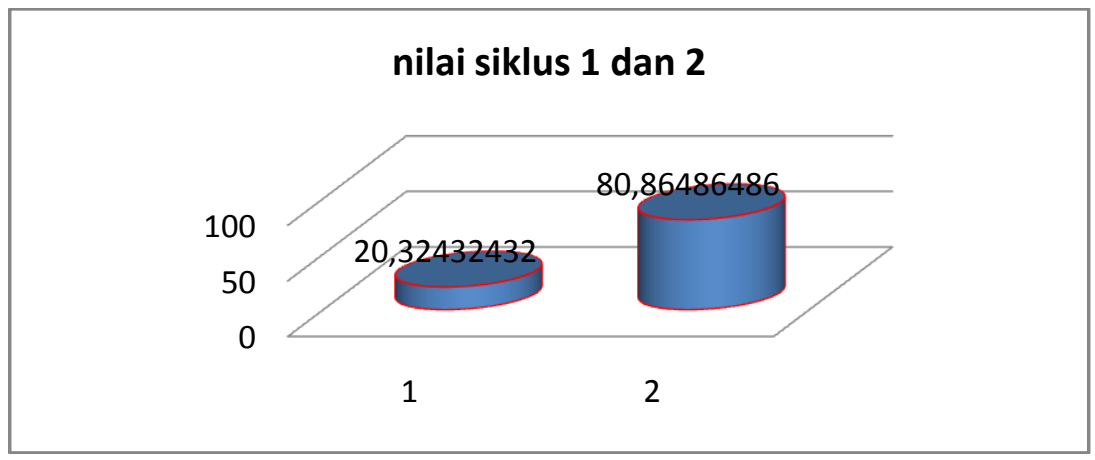

Grafik 4.2 Nilai siklus I dan II

Bila memperhatikan tabel di atas tergambar bahwa banyak siswa yang memiliki kemampuan pemecahan masalah pada siklus pertama mengalami peningkatan untuk tiap aspek ,tetapi pada siklus kedua untuk aspek fleksibelitas mengalami penurunan. Jadi di simpulkan berdasar kriteria yang di buat, secara keseluruhan siswa belum mengalami peningkatan kemmpuan pemecahan masalah. Pembelajaran dengan pengajuan masalah hanya meningkatkan pada aspek pemahaman informasi terhadap masalah, kefasihan dan kebaruan menghasilkan jawaban. Selain itu dari hasil pengamatan aktivitas kemampuan siswa dapat diperoleh seperti pada Tabel 4.6. 
Tabel 4.6 Hasil pengamatan aktivitas siswa

\begin{tabular}{|c|c|c|c|}
\hline NO & Aspek yang diamati & I & II \\
\hline 1. & $\begin{array}{l}\text { Siswa terdorong menggunakan kemampuan } \\
\text { pemecahan masalah }\end{array}$ & Jarang & Sering \\
\hline 2. & $\begin{array}{l}\text { Siswa belajar dalam keadaan antusias dan } \\
\text { gembira }\end{array}$ & jarang & Sering \\
\hline 3. & $\begin{array}{lccc}\text { Siswa } & \text { mempunyai } & \text { kesempatan } & \text { untuk } \\
\text { mengemukaan pendapat dan mempresentasikan }\end{array}$ & Jarang & Sering \\
\hline 4. & Siswa berbagi dan bekerja sama & Sering & Sering \\
\hline 5. & $\begin{array}{l}\text { Siswa melakukan refleksi dan berpikir kembali } \\
\text { tentang apa yang dipelajari }\end{array}$ & Jarang & Sering \\
\hline 6. & Terjadi interaksi guru dan siswa & Sering & Sering \\
\hline
\end{tabular}

\section{Kesimpulan dan Saran}

\section{A. Kesimpulan}

Hasil penelitian ini menyimpulkan bahwa pembelajaran dengan pemecahan masalah dapat meningkatkan kemampuan pemecahan masalah matematis siswa, terutama aspek pemahaman konsep, proses, strategi, dan koneksi dalam pemecahkan masalah. Untuk argumentasi dan keakuratan masih belum meningkat. Hal ini kemungkinan karena bentuk maupun konteks masalah mempunyai pengaruh tersendiri bagi siswa.

Hasil lain menunjukkan bahwa :

1. Kemampuan pemecahan masalah mengalami kemajuan atau peninggkatan dengan ditunjukkan semakin banyaknya siswa yang mencapai skor lebih dari $60 \%$ dari skor maksimum pada setiap siklus.

2. Kinerja siswa dalam merencanakan masalah mengalami perkembangan yang cukup baik, yaitu siswa lebih menggunakan kreatifan untuk memecahkan masalah sekitar.

3. Dengan pembelajaran model PMR, siswa lebih memberi respon positif dan dapat mengembangkan kreasi penyelesaian suatu masalah.

\section{B. Saran}

Berdasarkan hasil penelitian dapat disarankan bahwa :

1. Meskipun penerapan kemempuan pemecahan masalah belum meningkat semua aspek, tetapi menunjukkan manfaat dalam meningkatkan pembelajaran matematika, sehingga dapat diterapkan untuk materi yang lain maupun di kelas lain.

2. Perlu menggunakan metode yang bervariasi agar aktivitas siswa semakin aktif. 


\section{DAFTAR PUSTAKA}

Fauzan, Ahmad. 2004. Eksperimentasi Pembelajaran Matematika Pada Pokok Bahasan Melalui Pendekatan Realistik Ditinjau Dari Kemampuan Siswa, (online) Diakses 05 Oktober 2005

Fauzi, Amin.2002. Pengembangan Perangkat Pembelajaran Matematika Realistik Pokok Bahasan Pembagian di Kelas V SD. Surabaya komprehensif PPs UNESA

Gravemeijer, K. 1994. Developing Realistic Mathematics Education. Ultrecht: Freudenthal Institute.

Ruseffendi, E, T. (1991). Pengantar kepada Membantu Guru Mengembangkan Kompetensinya dalam Pengajaran Matematika untuk Meningkatkan CBSA. Bandung: Tarsido

Ruseffendi, H.E.T. (2006). Pengantar Kepada Membantu Guru Mengembangkan Kompetensinya Dalam Pengajaran Matematika Untuk Meningkatkan CBSA. Bandung: Tarsito.

Schoenfeld (1992). The Influence of Technological Advances on Students Mathematical Learning. (Dalam: Handbook of International Research in Mathematical Education. Ed. Lyn D. English). New Jersey: NCTM

Soedjadi. 2002. Upaya Guru Dalam Meningkatkan Hasil Belajar Matematika Melalui Pendekatan RME, ( online), Diakses 05 Oktober 2005 